\title{
SISTEM TEKNOLOGI PEMBUATAN GULA AREN DI KAMpung KUTA, KeCAMATAN TAMBAKsaRI, KABUPATEN GIAMIS
}

\author{
SYSTEM OF TECHNOLOGY IN MANUFACTURING PALM SUGAR \\ IN KUTA VILLAGE, TAMBAKSARI, CIAMIS
}

\author{
Oleh Yanti Nisfiyanti \\ Balai Pelestarian Nilai Budaya Bandung \\ Jln. Cinambo No. 136 Ujungberung - Bandung \\ Email:yantinisfiyanti@ymail.com
}

\begin{abstract}
Abstrak
Kearifan lokal masyarakat Kampung Kuta hingga kini tetap terpelihara dengan baik karena tatanan sosial yang dijalankan masyarakat dan pemangku adat setempat mengacu pada aturan adat yang berlaku secara turun-temurun. Di dalam memelihara sumber daya alam untuk kelangsungan hidup mereka dari generasi ke generasi, masyarakat Kuta menerapkan sistem teknologi yang diwariskan oleh leluhurnya untuk mengolah pertanian, baik yang dilakukan di sawah maupun di ladang. Salah satunya adalah menerapkan sistem teknologi tradisional dalam memelihara dan mengolah pohon aren. Pohon aren yang tumbuh subur di Kampung Kuta menjadi bagian terpenting dalam kehidupan warga yang keberadaannya diatur oleh adat setempat. Masyarakat Kuta memanfaatkan aren dari akar hingga buahnya, baik untuk keperluan sehari-hari maupun upacara. Pembuatan gula dari aren untuk upacara dapat digunakan sebagai bahan berbagai penganan sesajen, sedangkan untuk keperluan sehari-hari, gula aren di antaranya digunakan sebagai bahan makanan penambah tenaga. Dalam proses pembuatan gula aren tersebut terkandung pengetahuan tradisional tentang pengawetan bahan, perawatan alat, dan filosofi aren. Adapun penelitian ini menggunakan metode deskriptif-analitis.
\end{abstract}

Kata kunci: gula aren, teknologi tradisional, Kampung Kuta

\begin{abstract}
The society of Kuta village has been preserving their local wisdom because their elders as well as their social order refer to customary rules that have been run for generations, either in preserving natural resources or cultivating lands. One of their local wisdoms is traditional system of technology to cultivate and to process palm trees. To the Kuta society, palm trees (aren, Arengata pinnata) are important part of their lives, and they utilize almost every parts of the tree from the roots up to the fruit, either for
\end{abstract}


daily life or ceremony. They make palm sugar for offerings in ceremonies, and it is considered as energizer in daily life. The process of making palm sugar contains traditional knowledge of food preservation, tools maintenance and the philosophy of palm itself. This research conducted by descriptive-analytic approach.

Keywords: palm sugar, traditional technology, Kuta village.

\section{A. PENDAHULUAN}

Manusia karena kelengkapan fisiknya menjadikannya berbeda dengan makhluk lain ciptaan Tuhan. Selain itu, manusia memiliki kelebihan karena berkebudayaan yang membuatnya dapat beradaptasi dengan lingkungan di mana pun dia hidup. Oleh karena itu, dengan kemampuan dan kelebihan yang dimilikinya, manusia dapat bertahan hidup tidak hanya karena dapat menyesuaikan diri dengan lingkungannya, tetapi juga dapat menguasai alam di sekitarnya. Kendati demikian, hal itu diperolehnya dengan cara belajar sehingga dapat menerapkannya dalam kehidupan. Arti kebudayaan itu sendiri adalah keseluruhan sistem gagasan, tindakan dan hasil karya manusia dalam kehidupan yang dihasilkan manusia dalam kehidupan yang dijadikan milik manusia dengan belajar (Koentjaraningrat, 1985:180).

Salah satu karya manusia adalah adanya pengetahuan cara bercocok tanam dan pengolahan hasilnya menjadi makanan. Hal itu berlangsung dalam kurun waktu yang lama melalui percobaanpercobaan yang akhirnya berhasil. Sistem teknologi tradisional merupakan salah satu wujud kebudayaan universal yang dimiliki oleh semua masyarakat asli dan lokal. Sistem teknologi diturunkan dari generasi ke generasi, baik secara lisan maupun tulisan.

Salah satu warisan teknologi leluhur yang hingga kini masih digunakan adalah pembuatan gula aren pada masyarakat Kampung Kuta di Desa Karangpaninggal, Kecamatan Tambaksari. Keberadaannya secara tidak langsung mampu memelihara kelestarian alam di sekitarnya yang menjadi sumber penghidupan mereka dalam jangka waktu yang panjang.
Pembuatan gula aren di kalangan masyarakat Kampung Kuta konon sudah ada sejak generasi pertama.

Dalam masa teknologi modern bahkan canggih seperti sekarang ini, tidak dapat dipungkiri keberadaan gula aren yang mulai tergeser oleh produk modern sehingga perlu segera dilakukan penyelamatan pengetahuan dan teknologi tradisional sebagai sumber informasi bagi generasi sekarang agar tidak kehilangan jatidirinya.

Demikian pentingnya melestarikan warisan leluhur tersebut sehingga perlu didokumentasikan sistem pembuatan gula aren di Kampung Kuta yang di dalamnya terkandung informasi tentang cara-cara pengolahan aren menjadi gula dan adatistiadat masyarakat dalam memelihara kearifan lokalnya.

Penelitian ini dilakukan dengan metode kualitatif dengan pengumpulan data di lapangan dilakukan melalui wawancara. Perolehan data di lapangan dideskripsikan sehingga akan diperoleh gambaran empiris tentang kehidupan masyarakat Kampung Kuta dan pola-pola kebiasaan dalam kegiatan pembuatan gula aren. Selain wawancara dilakukan pula studi pustaka menggunakan buku-buku koleksi pribadi, Perpustakaan Daerah, serta kantor Dinas Kebudayaan dan Pariwisata.

\section{B. HASIL DAN BAHASAN}

\section{Gambaran Umum Kampung Kuta}

Secara administratif, Kampung Kuta atau Dusun Kuta berada di wilayah Kabupaten Ciamis, tepatnya di Kecamatan Tambaksari. Masyarakatnya masih teguh memelihara adat istiadat leluhur. Apabila diukur jarak Kampung Kuta dengan pusatpusat pemerintahan (desa, kecamatan, 
kabupaten, provinsi) adalah sebagai berikut:

- Dari Desa Karangpaninggal berjarak 1 $\mathrm{km}$;

- Dari pusat pemerintahan (Kecamatan Tambaksari) berjarak $4 \mathrm{~km}$;

- Dari ibu kota kabupaten (Kota Ciamis) berjarak $45 \mathrm{~km}$;

- Dari ibu kota Provinsi Jawa Barat (Bandung) berjarak $179 \mathrm{~km}$;

- Dari ibu kota negara (Jakarta) berjarak $578 \mathrm{~km}$.

Luas keseluruhan Kampung Kuta adalah 97 hektar yang terdiri atas 40 hektar berupa hutan keramat yang dilarang dimasuki sembarang orang dan 57 hektar lagi berupa lahan pertanian dan permukiman penduduk. Permukiman penduduk di Kampung Kuta ini terdiri atas 2 RW dan 4 RT yang menempati rumahrumah bentuk persegi panjang.

Salah satu rumah penduduk Kampung

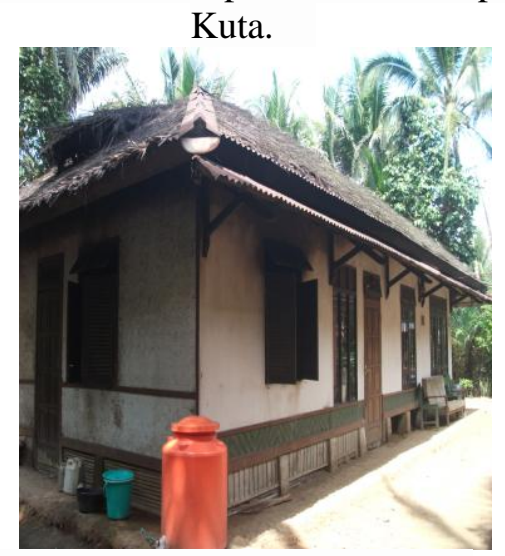

Sumber: Penelitian Tahun 2012

Berdasarkan fungsinya, tanah di Kampung Kuta terbagi atas tanah larangan dan tanah milik warga. Tanah larangan di Kampung Kuta merupakan hutan yang dilindungi agar tumbuhan dan hewan yang beragam tetap terjaga keasliannya. Warga setempat menyebut wilayah tersebut sebagai hutan keramat karena menurut kuncen setempat, di dalam hutan tersebut terdapat tempat-tempat atau lokasi petilasan leluhur Kuta, yaitu Ki Bumi yang dahulu bertugas menjaga keamanan Kuta.

Di dalam hutan keramat terdapat berbagai jenis pohon keras yang berumur puluhan sampai ratusan tahun. Selain itu, terdapat beragam tanaman yang berkhasiat sebagai obat. Di dalam hutan tersebut terdapat sungai-sungai yang airnya mengalir hingga ke perkampungan dan persawahan sehingga hutan tersebut berfungsi pula sebagai penyimpan sumber air yang sangat penting bagi kelangsungan hidup warga Kuta.

Kebun-kebun di Kampung Kuta memiliki potensi tanaman aren yang sangat besar sehingga para pedagang asal Kuta terkenal di luar kampungnya sebagai pembuat gula aren. Gula aren menjadi andalan perekonomian masyarakat sejak bertahun-tahun silam. Tanaman lain yang dikembangkan di perkebunan warga antara lain jagung, kacang, dan sayur-sayuran. Hasil perkebunan warga selain untuk konsumsi sehari-hari, juga menjadi sumber penghasilan para pedagang Kuta.

Tanah milik warga meliputi lahan persawahan, perkebunan, dan perumahan. Lahan yang bisa dimiliki oleh warga ini sangat terbatas sebagai hasil pembagian lahan yang luasnya diupayakan sama. Penambahan luas tanah bisa dilakukan dengan jalan membeli lahan apabila ada warga yang menjual tanahnya.

Adapun peruntukan lahan berdasarkan perhitungan luas rata-rata tiap keluarga sebagai berikut:

Lahan untuk perumahan 1,5 ha dibagi untuk 112 kepala keluarga (KK), masing-masing $133,92 \mathrm{~m}^{2}$ atau $0,13 \mathrm{ha}$; lahan kolam 10 ha dibagi untuk $112 \mathrm{KK}$ masing-masing $89,28 \mathrm{~m}^{2}$ atau 0,09 ha; lahan persawahan 17 ha dibagi untuk 112 KK masing-masing $152,78 \mathrm{~m}^{2}$ atau 0,15 ha; lahan kebun 119,5 ha dibagi $112 \mathrm{KK}$ masing-masing $218,75 \mathrm{~km}^{2}$ atau 0,80 ha. 
Pintu gerbang menuju pemukiman penduduk Kampung Kuta.

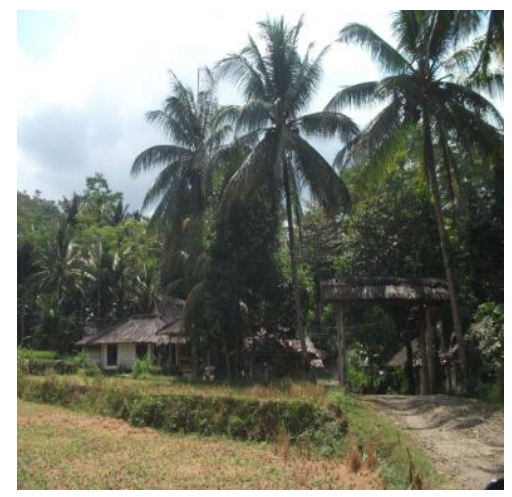

Sumber: Penelitian Tahun 2012

Penduduk Kampung Kuta yang berjumlah 327 jiwa ini seluruhnya menganut agama Islam yang kental dengan ekspresi religi kepercayaan bersifat mitos dan animisme. Hal itu terlihat dari ekspresi kesenian dan upacara tradisional, baik daur hidup maupun pertanian, yang senantiasa tidak terlepas dari pengaruh kepercayaannya.

Masyarakat Kuta mempunyai makanan khas yang khusus disajikan pada saat penyelenggaraan acara ritual tertentu. Mereka menyebut makanan tersebut sebagai makanan sajen atau sesajen, di antaranya adalah gula aren. Acara ritual tersebut di antaranya upacara Hajat Bumi, Nyuguh, dan upacara bangun rumah. Upacara Hajat Bumi dilakukan setiap tahun sesudah panen raya yang diikuti oleh warga satu desa. Upacara Nyuguh dilaksanakan sekali setiap tahun pada bulan Syafar. Upacara dipimpin oleh kuncen yang menjadi perantara warga dalam menyampaikan maksud. Maksud tersebut akan disampaikan oleh kuncen pada saat melafalkan doa dan mantera. Tujuan pelaksanaan upacara untuk menyampaikan terima kasih kepada Tuhan, dan roh leluhur yang telah mewariskan pohon aren, padi, kelapa, dan lain-lain. Adapun pembangunan rumah adat mengikuti aturan yang berlaku secara turun-temurun dengan ukuran 10 x 6 meter, menggunakan dinding anyaman bambu, lantai papan kayu, dan atap ijuk rumbia. Sebelum mulai pembangunan rumah biasanya dilakukan upacara.

\section{Pohon Aren di Kampung Kuta}

Pohon aren (bahasa Latin: arenga pinnala) atau di Indonesia dikenal pula sebutan enau dan airnya yang menetes di bagian tandan disebut nira. Pohon aren merupakan tanaman serbaguna. Bangsa Belanda mengenalnya aren palm atau zuikerpalm, dalam bahasa Sunda disebut kawung dan airnya disebut lahang.

Bagian-bagian dari pohon aren banyak manfaatnya bagi manusia. Buahnya untuk bahan makanan seperti manisan atau kolak kolang kaling; akarnya untuk bahan sapu ijuk; daunnya untuk bahan atap rumah, dan airnya atau nira untuk bahan gula aren.

Buah aren berbentuk bulat seperti peluru dengan diameter sekitar $4 \mathrm{~cm}$. Buah aren yang masak berwarna kuning kecokelat-cokelatan dan daging buahnya lunak. Ada 2 jenis pohon aren, yaitu aren genjah dan aren dalam. Aren genjah memiliki ciri pohon agak kecil dan pendek, sedangkan aren dalam pohonnya besar dan tinggi. Aren genjah memproduksi nira 1015 liter per tandan setiap harinya. Adapun dari satu tandan berisi 300 sampai 500 buah. Setiap aren memproduksi nira 20-30 liter per tandan setiap harinya.

Pohon induk yang bisa diambil sebagai sumber benih adalah yang sedang disadap niranya. Pohon aren dikenal sebagai tanaman hapaksantik, yaitu fase reproduktifnya membatasi pertumbuhan batang dengan daya tahan hidup mencapai 3 tahun.

Untuk mengetahui bahwa pohon induk terpilih sebagai sumber benih dapat dilihat dari bunga atau mayang betina yang memiliki produktivitas nira 20-30 liter per mayang setiap harinya. Produktivitas demikian tergolong tinggi. Oleh karenanya, perlu penyadapan nira dari mayang jantan pertama atau kedua. Tidak semua mayang jantan keluar (9-11 mayang) dan tidak semua pohon aren 
mengeluarkan nira. Apabila yang disadap mayang jantan pertama atau kedua produksi niranya banyak, maka pohon tersebut produktif untuk pohon induk sebagai sumber benih. Pohon yang terpilih sebagai sumber benih dengan produksi nira yang banyak, maka tidak dianjurkan untuk proses penyadapan pada tandan-tandan selanjutnya secara berturut-turut. Bila pohon induk disadap terus-menerus, maka akan berakibat tidak baik pada kualitas buah karena akan menghasilkan buah yang bijinya berkerut bahkan kempes sehingga buruk apabila dijadikan benih.

Apabila menanam pohon aren sendiri, maka harus dilakukan proses perkecambahan. Salah satu cara untuk memacu aktivitas perkecambahan benih aren adalah:

- Biji dikeringkan dengan cara dijemur selama 1-2 hari dalam keadaan panas matahari normal.

- Biji direndam selama 24 jam.

- Biji dimasukkan ke dalam kantong plastik dan ditutup rapat, baru dibuka setelah biji pecah dan kecambah muncul. Proses ini berlangsung selama 7 hari. Untuk mempercepat proses perkecambahan, maka ke dalam kantong plastik dimasukkan pula sekam padi.

Pemeliharaan /perawatan bibit dilakukan dengan penyiraman secara rutin; lalu penyiangan tumbuhan liar; penggemburan tanah agar sirkulasi oksigen dalam tanah berlangsung dengan lancar; dan pemupukan pohon agar cepat tumbuh dan subur.

Pengambilan nira dari pohonnya memerlukan keterampilan dan fisik yang kuat sebab selain petani harus mampu memanjat di ketinggian pohon, juga pengetahuan cara memperlakukan pohon ketika sudah disadap niranya agar kualitas dan kuantitas nira dapat dipertahankan setelah penyadapan. Misalnya, tandan yang sudah diambil niranya agar mampu mengeluarkan nira yang cukup banyak. Caranya dilakukan sebagai berikut.

Saat memanjat pohon aren, petani harus membawa pula lodong yang diselempangkan di bahu serta pisau yang diikat di pinggang. Di atas pohon, lodong yang telah terisi diganti dengan lodong baru. Sebelum memasang lodong tersebut pada tandan, maka permukaan tandan diiris kembali, lalu digosok menggunakan satu telapak tangan hingga keluar airnya. Selanjutnya, lodong yang kosong dipasang pada tandan tersebut dengan diikat tali dari akar atau tali rafia.

Untuk mencegah nira tercampur air hujan dan faktor kontaminasi lainnya, lodong menggunakan penutup dari pelepah kering atau ada pula yang membungkusnya dengan karung plastik atau semacamnya. Apa pun bahan penutupnya yang terpenting nira di dalam lodong terlindungi.

Aktivitas penyadap nira di atas pohon aren.
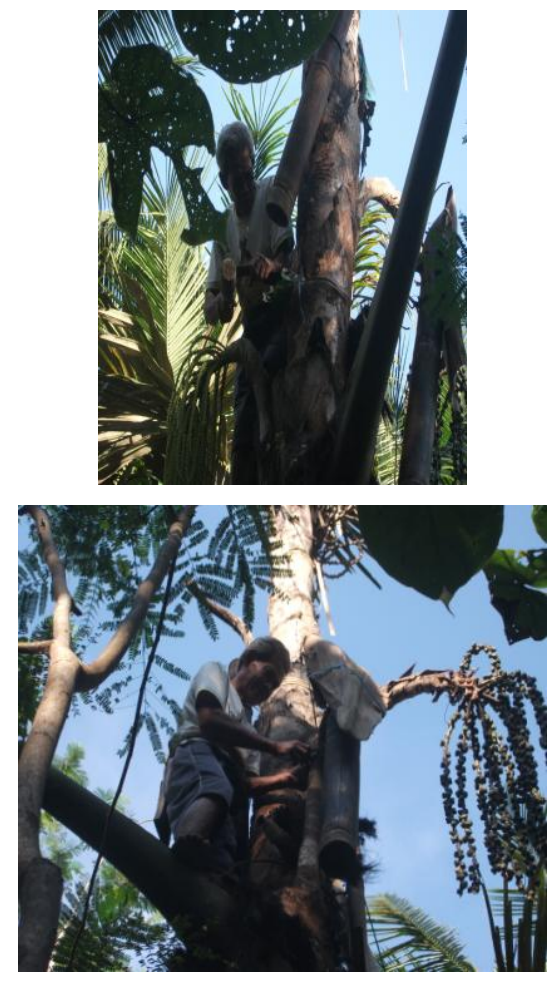

Sumber: Penelitian Tahun 2012

Pohon aren di Kampung Kuta tumbuh subur. Awalnya pohon aren 
tersebut tumbuh sendiri di hutan dan kebun petani yang secara tidak sengaja bibitnya dihasilkan dari kotoran binatang tupai. Tupai adalah binatang pemangsa buah aren yang biasanya setelah memakan buah aren, memproduksi kotoran di sembarang tempat sehingga bibit aren tersebut berserakan, lalu tumbuh.

Setelah nira yang dihasilkan pohon aren dapat diolah menjadi makanan, maka warga memeliharanya dan menanam bibitnya di sekitar tempat tinggal. Saatnya pohon aren berbuah perlu waktu bertahuntahun. Bertahun-tahun pula aren menjadi bagian dari kehidupan masyarakat Kampung Kuta. Keberadaan aren membuat kehidupan mereka berdenyut setiap hari. Saat pohon aren sudah bisa diambil niranya, maka setiap pagi dan sore hari, bapak tani pergi dari rumahnya menuju pohon aren miliknya sambil menyelempangkan dua buah lodong di bahunya dan sebilah pisau di pinggang. Selodong demi selodong, air nira tersebut dikumpulkan di rumah, lalu istrinya yang memasak nira tersebut sampai menjadi gula.

Penyadap nira dengan peralatan yang dibawanya.

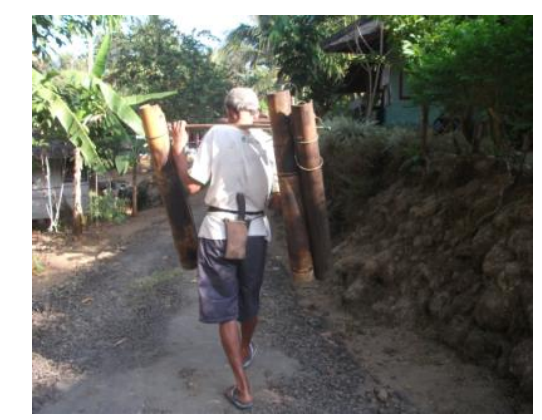

Sumber: Penelitian Tahun 2012

Untuk memelihara kelangsungan masyarakat dalam mengolah aren, mereka sepakat memberlakukan larangan menebang pohon aren yang tumbuh di sekitar perkampungan. Adanya larangan tersebut, membuat jumlah pohon aren di Kampung Kuta berlipat ganda. Bahkan pohon yang tumbuh beberapa tahun silam bertambah tiga kali lipat.

Pemerataan hasil aren bagi warga Kampung Kuta dilakukan untuk ketertiban dan kebersamaan warga. Penyadapan pohon aren dilakukan secara tertib sehingga 1.000 pohon aren yang sudah menghasilkan nira dibagi-bagikan kepada 400 warga. Setiap kepala keluarga mendapat bagian 7 pohon. Adapun hasil yang diperoleh dari penyadapan rata-rata setiap keluarga memperoleh 2,5 kilogram gula aren. Selain memperoleh pohon aren, warga mewarisi pula pengetahuan pembuatan gula aren dari leluhurnya sehingga hasil dari pohon aren tersebut dapat dimanfaatkan.

Antara masyarakat Kuta dengan gula aren terdapat hubungan fungsional dimana gula aren tidak dapat dipisahkan dari mereka karena bahan makanan tersebut menjadi unsur yang memberi pengaruh kuat pada budaya masyarakat Kuta dan memberi ciri komunitas ini sebagai penghasil gula aren. Untuk mempertahankan sumber daya alam tersebut dalam penyediaan bahan baku, maka dilakukan pelestarian pohon aren di wilayah Kampung Kuta.

Teori Fungsionalisme merupakan salah satu ilmu dalam antropologi yang menafsirkan masyarakat sebagai sebuah struktur dengan bagian-bagian yang saling berhubungan. Fungsionalisme menafsirkan masyarakat secara keseluruhan dalam hal fungsi dari elemen-elemen konstituennya ; terutama norma, adat, tradisi dan institusi. Dalam hal tradisi, pembuatan gula aren sebagai salah satu pengetahuan yang dimiliki oleh leluhur selalu diwariskan secara turun-temurun dan menjadi bagian hidup masyarakat Kuta.

Hubungan bersifat fungsional tampak pada manfaat gula aren bagi warga, yaitu sebagai sumber energi yang dapat ditambahkan pada berbagai penganan. Penganan yang manis-manis dikonsumsi untuk menambah tenaga bagi mereka yang sehari-hari bertani. Selain itu, fungsi gula aren untuk keperluan sesajen 
dalam upacara seperti membuat bubur merah. Selain dikonsumsi sendiri, gula aren tersebut diperjualbelikan sehingga dapat membantu perekonomian petani.

Pohon aren dalam masyarakat Kuta merupakan subtansi yang mengikat petani pada tradisi leluhurnya. Tradisi yang dijalankan oleh petani aren adalah melaksanakan ritual ketika akan memanen pohon aren. Ritual tersebut dilakukan pada pohon aren yang baru pertama kali diambil niranya. Waktunya pada pagi hari saat bersiap-siap menyadap nira dengan membawa pedupaan dan perlengkapan sesajen. Maksud ritual tersebut untuk menyampaikan rasa syukur serta memohon izin kepada Sang Pencipta dan roh para leluhur yang diungkapkan melalui mantera dan doa. Masyarakat menyebut ritual tersebut dengan ngajeunahkeun, ngajinahkeun atau ngamimitian kawin yang dalam bahasa Indonesia sama dengan mengawinkan.

Adanya upaya pemerataan hasil aren dengan dilakukan pembagian pohon aren kepada setiap kepala keluarga di Kampung Kuta mengandung makna kebersamaan yang mencerminkan betapa kuatnya nilai tolong-menolong pada masyarakat Kampung Kuta. Koentjaraningrat (1985) menyebutkan, bahwa nilai yang melatarbelakangi segala aktivitas tolongmenolong antarwarga sedesa adalah nilai budaya yang berkenaan dengan hakikat hubungan antarmanusia yang mengandung empat konsep, yaitu: 1) Manusia tidak hidup sendiri tetapi dikelilingi oleh komunitasnya, masyarakatnya, dan alam di sekitarnya. 2) Pada hakikatnya manusia bergantung pada sesamanya. 3) Memelihara hubungan baik dengan sesamanya terdorong oleh jiwa sama rasa. 4) Hidup bersama dengan sesamanya dalam komunitas terdorong oleh jiwa sama tinggi sama rendah.

Keempat unsur yang melatari aktivitas tolong-menolong tersebut kuat berakar dalam kehidupan masyarakat Kuta karena mereka memiliki tradisi yang sama.

\section{Manfaat Gula Aren di Kampung Kuta}

Gula aren tidak hanya sekadar bahan pelengkap makanan sehari-hari, tetapi secara religius sangat penting artinya bagi kehidupan warga Kuta dalam memenuhi keperluan upacara adat atau selamatanselamatan dalam menyajikan makanan dan minuman, baik untuk sesajen maupun sajian bagi para undangan. Selain sebagai sumber makanan, gula aren dalam masyarakat Kampung Kuta bermanfaat pula untuk memelihara kesehatan, misalnya untuk meningkatkan tenaga. Sebagai masyarakat yang sehari-hari bekerja keras, maka badan yang sehat dan kuat sangat dibutuhkan untuk menunjang pekerjaan sehari-hari sebagai petani.

Hingga kini, pengetahuan tentang pembuatan gula aren pada masyarakat Kampung Kuta terus hidup karena didukung oleh kondisi lingkungan dan budaya masyarakat setempat. Meskipun produksi kelapa di Kampung Kuta cukup banyak, produksi buah aren lebih banyak dan masyarakat menggunakannya sebagai bahan baku pembuatan gula. Pertimbangan kesehatan bahwa aren lebih aman untuk kesehatan daripada kelapa, maka digunakanlah aren untuk bahan pembuatan gula.

Adapun gula aren yang dibuat di Kampung Kuta ada dua macam, yaitu gula aren semut dan gula aren cetak. Dari kedua janis gula tersebut yang sering dibuat oleh masyarakat Kampung Kuta adalah gula aren cetak. Gula aren semut lebih sulit membuatnya, tetapi lebih disukai konsumen daripada gula aren cetak karena lebih praktis mengonsumsinya. Gula aren semut berbentuk butiran halus seperti gula pasir, namun berwarna kuning kecokelatan. Adapun gula aren cetak keras. Saat digunakan untuk pemanis minuman harus diiris terlebih dahulu. Gula aren semut yang dibuat secara tradisional dilakukan dengan mengaduk dan menggosok kentalan gula aren secara terus-menerus sampai terjadi pembentukan kristal, lalu dilakukan pengayakan untuk 
menghasilkan kristalan gula semut yang lebih halus.

Apabila diperhatikan secara saksama, gula aren yang dibuat di Kampung Kuta beragam warnanya, yaitu cokelat keputih-putihan, cokelat kemerahmerahan, dan cokelat kehitam-hitaman. Hal itu terjadi karena faktor kualitas bahan dalam hal ini nira. Apabila niranya berwarna keruh, maka gula aren yang dihasilkannya berwarna cokelat keputihputihan; nira yang berwarna bening menghasilkan gula aren cokelat kemerahmerahan; dan nira yang berwarna putih menghasilkan gula aren cokelat kehitamhitaman. Menurut beberapa orang warga, gula aren berwarna cokelat keputih-putihan dianggap berkualitas karena rasanya lebih enak daripada yang lain. Oleh karena itu, gula aren yang berwarna cokelat keputihputihan harganya lebih tinggi daripada gula aren berwarna lain. Selain lebih enak, bahan yang digunakan lebih banyak dan proses perebusan berlangsung lebih lama.

Gula aren produksi masyarakat Kampung Kuta dijual ke Pasar Rancah, yaitu pasar terdekat yang berjarak 15 kilometer dari kampung. Biasanya, mereka menumpang truk, namun apabila tidak bisa pergi sendiri ke pasar, ada orang yang datang ke rumah-rumah pembuat gula aren untuk mengambil dan menjualnya di Pasar Rancah. Setiap hari Rabu dan Sabtu para penjual gula aren ini menjual produksinya di Pasar Rancah.

Harga gula aren ditentukan oleh kalangan petani, tetapi tidak menutup kemungkinan harga ditentukan oleh pasar. Tiga tahun yang lalu (2009) harga gula Rp 6.000 per bonjor dengan isi 10 batok. Tahun ini (2012) ada yang menjual gula aren produksinya seharga $\mathrm{Rp} 18.000-\mathrm{Rp}$ 20.000 per bonjor setelah mengetahui harga gula aren di luar jauh di atas harga di kampungnya. Selain ke pasar, gula aren tersebut adakalanya dijual ke tetangga yang kebetulan membutuhkannya dengan harga yang lebih rendah dibanding ketika menjual ke pihak luar.

\section{Pembuatan Gula Aren}

Usaha pembuatan gula aren yang dilakukan oleh masyarakat Kampung Kuta bersifat industri rumah tangga. Proses pembuatannya masih sederhana dengan memanfaatkan bahan-bahan dari alam dan peralatan yang dibuat sendiri dari bahanbahan alam pula.

Sebenarnya tidak sulit cara membuat gula aren karena tidak banyak tahapannya. Akan tetapi, cerita gula aren di balik pembuatannya sungguh mengagumkan. Betapa tidak, dari nira yang dikumpulkan sepanjang hari dengan menyimpan wadahnya di atas pohon yang tingginya sekitar 20 meter ini bukan pekerjaan mudah, perlu memanjat dengan bantuan tangga sederhana, tetapi teruji kekuatannya. Leluhur mereka melakukannya, yang kemudian diikuti oleh keturunannya hingga sekarang. Selain itu, dari nira yang cair tersebut, para leluhur berhasil menciptakan makanan padat berwarna kecokelat-cokelatan dengan rasa jauh berbeda dengan rasa awalnya. Ketika masih cair, air nira ini berasa dingin, asam, dan tidak begitu manis dan setelah menjadi gula rasanya menjadi benar-benar manis dan beraroma.

Pembuatan gula aren di Kampung Kuta sudah dilakukan selama ratusan tahun hingga sekarang dan sudah menjadi tradisi turun-temurun masyarakat Kampung Kuta. Adapun bahan pokok yang digunakan dalam pembuatan gula aren adalah cairan manis yang dinamakan nira. Satu ketel nira bisa menghasilkan 5 batok gula aren. Pada saat penggodokan tidak ada bahan lain yang dicampurkan, tetapi untuk mengawetkan nira supaya tidak cepat basi diperlukan bahan-bahan lain seperti:

a. Raru, terbuat dari daun jeungjing yang diikat kemudian dikeringkan.

b. Kayu nangka, berupa irisan kayu nangka yang dikeringkan.

c. Cuka sebagai bahan campuran kayu nangka. 
Pengawet nira dari kayu nangka dan daun jeungjing.
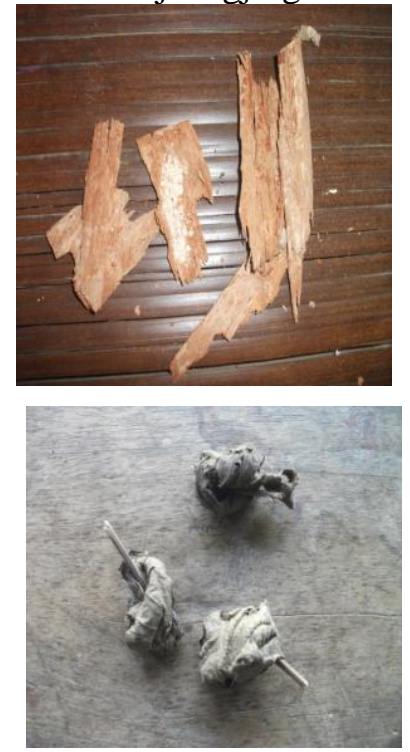

Sumber: Penelitian Tahun 2012

Masyarakat Kampung Kuta telah diwariskan oleh leluhurnya pengetahuan tentang cara memanfaatkan alam menjadi peralatan kerja. Selain itu, ditunjang oleh pengalamannya, membuat mereka terampil dalam memanfaatkan hasil alam tersebut. Salah satu contoh, mereka terampil membuat alat-alat yang akan digunakan untuk membuat gula aren, seperti lodong tempat menampung air nira langsung dari pohonnya. Lodong dibuat dari bambu jenis tertentu, yaitu bambu surat. Jenis bambu ini kelebihannya memiliki tebal dan ukuran diameternya besar. Sebagian peralatan yang digunakan berbahan logam, seperti ketel dan susuk, tidak dibuat sendiri.

Dalam pembuatan gula aren disediakan berbagai peralatan yang digunakan untuk pengambilan air nira hingga pembungkusan gula. Peralatan tersebut sebagai berikut:

a. Lodong atau gombong, berupa bilah bambu yang berdiameter besar. Salah satu ujungnya merupakan ruas tertutup sebagai bagian bawahnya, sedangkan ujung satu lagi terbuka sebagai bagian atas. Fungsi lodong atau gombong untuk mengambil air nira atau lahang yang setiap pagi atau sore mulai ditadahi.

b. Katel atau ketel, terbuat dari logam besi yang berfungsi sebagai tempat mendidihkan nira.

c. Pangguis, guguis atau susuk. Pangguis ada dua macam, yang satu terbuat dari bahan kayu yang salah satu ujungnya lebih lebar dari ujung lainnya yang jadi pegangan. Fungsinya untuk mengaduk. Pangguis satu lagi berupa batok kelapa yang fungsinya untuk mengambil atau mengerok nira yang akan dicetak. Adapun susuk terbuat dari bahan logam yang berfungsi sebagai pengaduk.

d. Cetakan, berupa bilahan bambu setebal $3 \mathrm{~cm}$ yang berbentuk lingkaran seperti gelang, berfungsi sebagai alat mencetak.

e. Ebeg, berupa papan landasan yang berfungsi sebagai alas untuk mencetak.

f. Puputan, terbuat dari bambu yang fungsinya untuk memanaskan lodong agar air nira tidak basi.

g. Barala kalapa, berupa daun kelapa atau daun nira yang dikeringkan. Fungsinya untuk membungkus gula aren.

h. Tali, bagian dari pembungkus gula aren berupa bambu yang diiris tipis.

i. Nyiru, terbuat dari anyaman bambu yang berfungsi sebagai alat menyimpan gula aren saat baru dilepas dari cetakan. 
Sebagian peralatan dalam pembuatan gula aren, ebeg dan cetakan.
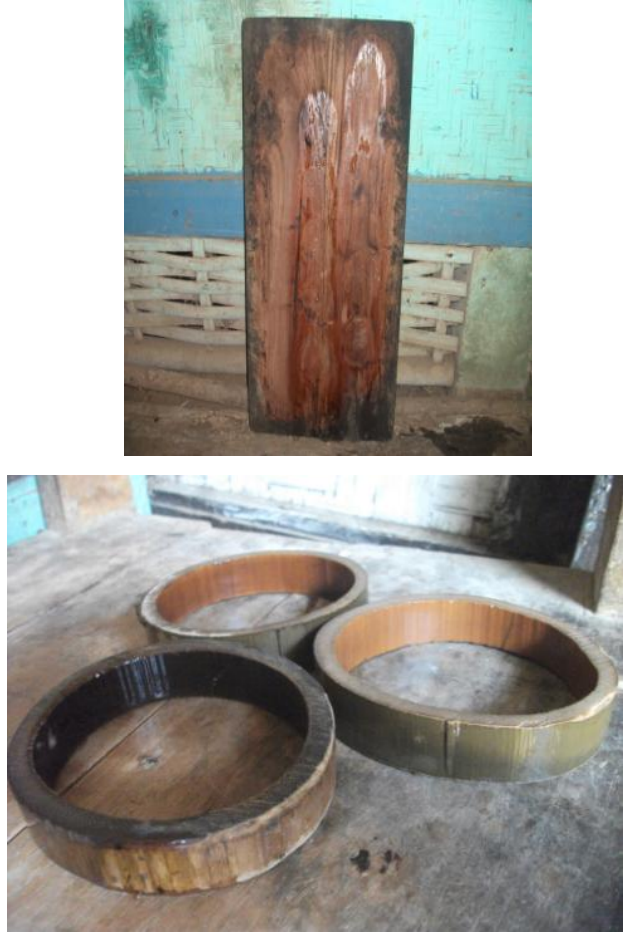

Sumber: Penelitian Tahun 2012

Peralatan yang berasal dari kayu dan bambu akan mudah rusak apabila tidak dilakukan perawatan setelah digunakan terus-menerus dalam pembuatan gula aren. Oleh karena itu, pembuat gula aren yang sudah berpengalaman biasanya memiliki pula pengetahuan tentang perawatan alatalat yang sudah digunakan. Pengetahuan tersebut diperolehnya dari hasil melihat orang tua atau saudaranya yang sudah biasa membuat gula aren. Misalnya, cetakan harus terawat baik, maka untuk membersihkannya direndam air. Lodong atau gombong dibersihkan menggunakan heurab. Peralatan tersebut dapat digunakan berkali-kali. Apabila lodong atau gombong retak sehingga bocor, maka harus diganti dengan yang baru.

Adapun tahap-tahap pembuatan gula, pertama nira yang baru diambil dari pohonnya dituangkan ke dalam ketel lalu direbus tanpa ditambah bahan lain. Ketika rebusan mulai mendidih, saatnya dilakukan pengadukan menggunakan susuk atau pangguis. Pengadukan dilakukan terusmenerus, sekitar 5 jam, untuk menghindari pengerakan. Setelah nira habis atau saat, tiba saatnya mencetak gula aren menggunakan cetakan bambu. Pengambilan gula aren dari ketel menggunakan batok (tempurung) kelapa. Gula aren dalam cetakan akan segera menjadi padat dan keras. Gula aren yang sudah dingin akan mudah lepas dari cetakan. Tahap akhir, gula aren dibungkus dengan daun aren kering. Biasanya, setiap bungkus atau bonjor berisi 10 gandu atau batok gula aren.

Proses pembungkusan gula aren.
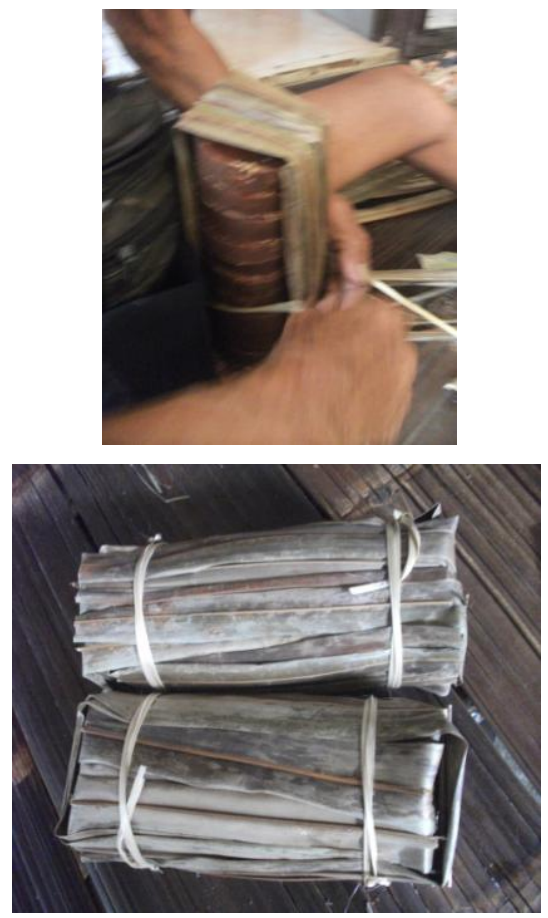

Sumber: Penelitian Tahun 2012

Dalam proses pembuatan gula aren terdapat istilah-istilah khusus yang menunjukkan tahap-tahap pengolahan seperti:

Legen : nira baru diambil dari pohon.

Ngawedang : sudah proses direbus tetapi masih cair. 
Meueut : sudah mengeras tetapi belum kolot.

Kolot : apabila ditetes ke dalam air dingin langsung mengkel.

Proses penggodokan aren hingga kolot biasanya berlangsung lama, berjamjam. Satu ketel penuh dari sekitar 2 kali penyadapan direbus sekitar 5 jam. Adapun hasilnya dari satu ketel aren sekitar 8 gandu gula.
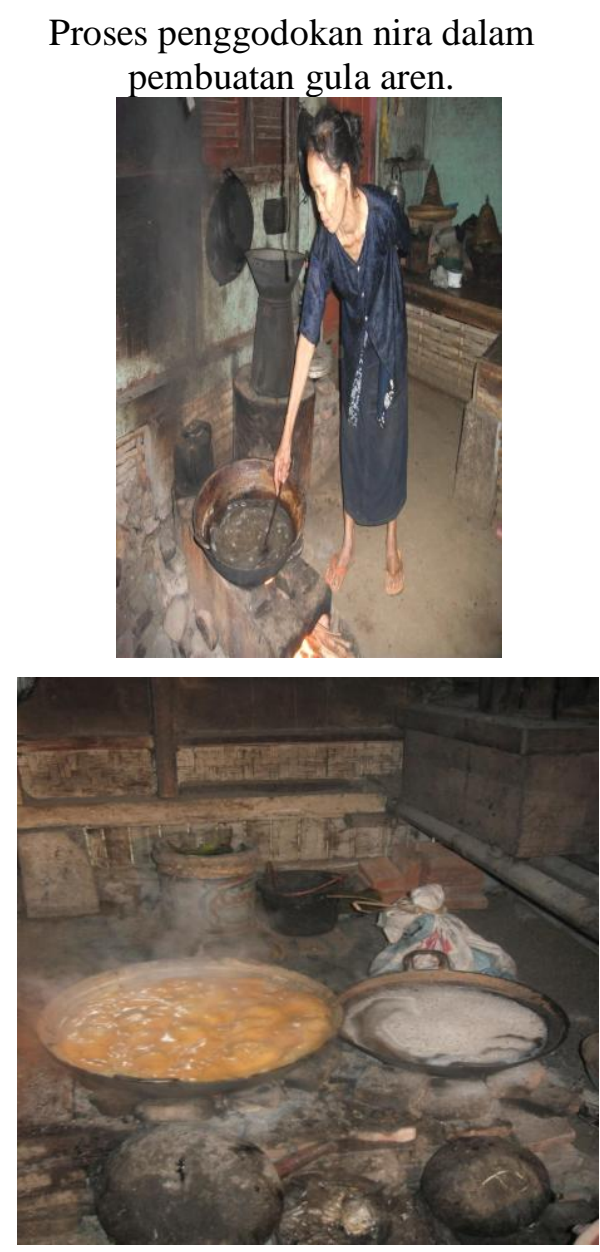

Sumber: Penelitian Tahun2012

\section{PENUTUP}

Gula aren bagi masyarakat Kampung Kuta bermanfaat bagi segala jenis makanan dan minuman. Gula aren tersebut dapat menjaga stamina badan supaya tetap kuat. Keadaan ini menjadi kebutuhan bagi petani yang setiap hari bekerja keras di sawah atau ladang. Pengetahuan masyarakat tentang kadar lemak yang rendah pada gula aren membuat mereka khususnya yang berusia dewasa memilih gula aren daripada gula dari buah kelapa.

Apabila melihat manfaatnya yang besar, maka keberadaan pohon aren di Kampung Kuta perlu dilestarikan, demikian pula penerapan sistem teknologi pembuatan gula aren perlu dipertahankan agar dapat dirasakan manfaatnya secara langsung oleh warga. Terlebih dari itu, keberadaan sistem teknologi tradisional sebagai warisan turun-temurun masyarakat Kuta kini mulai dibayangi teknologi modern yang setiap saat menerpa kehidupan mereka sebagai dampak interaksi warga dengan dunia luar.

Nilai yang berlaku dalam masyarakat Kampung Kuta merupakan perangkat nilai yang diwariskan oleh leluhurnya. Perangkat nilai tersebut selanjutnya menjadi pedoman hidup masyarakat generasi penerus dalam mengolah segala sesuatu yang diwariskannya. Dalam hal ini masyarakat Kampung Kuta memiliki kearifan lokal yang menjadi pegangan dalam memperlakukan dan mengolah alam, seperti ketika memanen aren untuk membuat gula.

Masyarakat Kampung Kuta sangat identik dengan gula aren karena hampir setiap keluarga membuat gula aren. Dari kegiatan sehari-hari yang relatif sama ini tercermin nilai kesetaraan, kebersamaan, dan religius. Pemanfaatan gula aren selain untuk kebutuhan sehari-hari dan penghasilan keluarga, juga untuk keperluan penganan pada upacara atau selamatan yang diolah secara gotongroyong.

Nilai keselarasan dan keseimbangan antara warga Kampung Kuta dengan roh leluhur tercermin pada tradisi ritual yang dilakukan dengan menyediakan makanan khas untuk roh leluhur. 
Berikut ini beberapa saran yang berkaitan dengan keberlangsungan pembuatan gula aren di Kampung Kuta.

- Peran pemangku adat dan dukungan warga setempat dalam melestarikan kekayaan alam dan tradisi di Kampung Kuta jangan pernah surut sehingga pembuatan gula aren pun akan dapat dipertahankan.

- Gula aren bagi warga Kuta tidak hanya berfungsi sebagai sumber energi juga untuk memenuhi kebutuhan penyediaan sesaji upacara. Terlebih dari itu gula aren dapat diandalkan sebagai sumber ekonomi keluarga. Perkembangan ilmu pengetahuan dan teknologi secara berangsur akan berpengaruh pada kehidupan masyarakat Kampung Kuta. Bukan tidak mungkin akan berpengaruh pula pada pemasaran gula aren. Oleh karena itu, perlu dilakukan peningkatan dari segi kualitas dan pengemasan.

- Pengembangan pohon aren di Kampung Kuta akan meningkatkan produk gula aren. Namun demikian, peran pemerintah diharapkan dapat membantu melancarkan pemasarannya sehingga masyarakat Kampung Kuta yang menggantungkan hidupnya dari hasil penjualan gula aren akan terangkat perekonomiannya.

\section{DAFTAR SUMBER}

\section{Buku}

Djiwapraja, Dodong, dkk. 2000.

Ensiklopedi Sunda, Alam manusia dan Budaya termasuk Budaya Cirebon dan Betawi. Jakarta: Pustaka Jaya.

Efendi, Rahmad, dkk. 2010.

Antropologi dalam Teropong

Antropologi Kesehatan, Laporan

Hasil Observasi Kampung Kuta.
Bandung: Universitas Padjadajaran

Bandung.

Koentjaraningrat. 1985.

Pengantar Antropologi Cetakan 5. Jakarta: Aksara baru.

\section{Internet}

Adegusti.wordpress.com/2011/01/27 /batikkawung/ 